\title{
Common microbial etiology of abnormal vaginal discharge among sexually active women in Dhaka, Bangladesh
}

Md. Abdullah Yusuf', Mahmuda Chowdhury², KM Shahidul Islam³, Eliza Omar Eva', Ahmad Raihan Sharif, Md. Khalilur Rahman ${ }^{6}$, Abdur Rabban Talukder , Shahin Ara Begum ${ }^{8}$

${ }^{1}$ Lecturer, Department of Microbiology, Shaheed Suhrawardy Medical College, Dhaka; ${ }^{2}$ Professor and Head, Department of Community Medicine, Shaheed Suhrawardy Medical College, Dhaka; ${ }^{3}$ Professor, Department of Microbiology, Dhaka Medical College, Dhaka; ${ }^{4}$ Assistant Professor, Department of Pharmacology, Shaheed Suhrawardy Medical College, Dhaka; ${ }^{5}$ Medical Officer, Department of Virology, Institute of Epidemiology Diseases Control \& Research, Dhaka; ${ }^{6}$ Assistant Professor,

Department of Radiology and Imaging, Dhaka Medical College, Dhaka; ${ }^{7}$ Senior Consultant, Department of Surgery, General Hospital, Sirajgonj; ${ }^{8}$ Assistant Professor, Department of Microbiology, Comilla Medical College, Comilla, Bangladesh.

\section{Abstract}

Abnormal vaginal discharge is a common symptom of genital infection in women. The aim of the present study was to evaluate the various causes of vaginal discharge in sexually active females. A cross-sectional study was undertaken among women aged 15 to 45 years with abnormal vaginal discharge, with or without itching attended at Sir Salimullah Medical College, Dhaka for a period of 6 months. After making the clinical diagnosis, appropriate tests for diagnosing candidiasis, trichomoniasis, gonorrhea and bacterial vaginosis were done. Among all patients, organisms responsible for abnormal vaginal discharges were found in $94.8 \%$ of the cases, of which vaginal candidiasis $(53.6 \%)$ was the most common, followed by bacterial vaginosis $(29.2 \%)$, trichomoniasis $(10.8 \%)$, gonorrhea $(1.2 \%)$ and non-specific other urogenital causes $(5.2 \%)$. The most common age groups affected by vaginal candidiasis, bacterial vaginosis and trichomoniasis were $26-35$ years $(64.9 \%), 26-35$ years $(27.6 \%)$ and $15-25$ years $(52 \%)$ respectively. Gonorrhea was recorded in the age group of $15-25$ years $(66.7 \%)$. Most of the organisms were isolated in the age group of $30-40$ years. The causative agent of vaginal candidiasis was the leading cause of vaginal discharge in the age group of sexually active women and next to it was the bacterial vaginosis. A lower rate of Trichomonas vaginalis was found in our study in comparison to other studies.

Keywords: Vaginal discharge, Vaginal candidiasis, Bacterial vaginosis, Trichomoniasis.

\section{Introduction}

Abnormal vaginal discharge is a common clinical problem among sexually active women with many etiologies. Approximately 10 million office visits each year are attributed to vaginal discharge complaints. ${ }^{1}$ Many women with vaginal complaints self-treat incorrectly with over-thecounter drugs. ${ }^{2}$ Healthcare providers themselves may miss the correct diagnosis if they fail to confirm the diagnosis with the proper laboratory test.

The vagina, ectocervix and endocervix all are susceptible to various pathogens, depending on the type of epithelium present and other factors in the microenvironment. The stratified squamous epithelium of the vagina and ectocervix is susceptible to infection with Candida species and Trichomonas vaginalis. The columnar epithelium of the endocervix is susceptible to infection with Neisseria gonorrheae and Chlamydia trachomatis. Herpes simplex

\section{Practice points}

- Women should be more conscious regarding abnormal vaginal discharge due to high frequency of infection.

- Candida species is still the most common etiological agents among sexually active women.

- Younger women are more prone to develop vaginal candidiasis.

- Isolation rate of causative agent of bacterial vaginosis is alarming among more than 35 years of old women as it is the etiological factors of bad obstetrical and fetal outcomes.

- Trichomonas vaginalis has still a low rate of isolation among all other organisms.

Correspondence: Dr. Md. Abdullah Yusuf, Apartment: Mega Happy Nook, Flat \# C2, House \# 19/15, Babar Road, Block-B, Mohammadpur, Dhaka-1207, Bangladesh. E-mail: ayusuf75@yahoo.com.

South East Asia Journal of Public Health 2011:1:35-39. (C) 2011 Yusuf et al., publisher and licensee Public Health Foundation Bangladesh. This is an Open Access article which permits unrestricted non-commercial use, provided the original work is properly cited. 
virus may infect both types of epithelium ${ }^{2}$. Infection caused by any of these organisms can lead to vaginal discharge. Identifying its specific cause can be a challenging task, because a large number of pathogens cause vaginal and cervical infections, and several infections may co-exist. Patient's history and physical examination finding(s) may suggest a diagnosis.

Abnormal vaginal discharge is usually related to one of the three conditions, like bacterial vaginosis (BV), vulvovaginal candidiasis (VC), and trichomoniasis. ${ }^{1}$ These infections usually respond to appropriate treatment; however, misdiagnosis and inappropriate treatment may occur. Other less common forms of vaginal symptoms include atrophic vaginitis, chemical irritation, lichen planus, allergic vaginitis, desquamative vaginitis, and foreign body. ${ }^{1-4}$ Bacterial vaginosis, which is primarily characterized by a malodorous discharge, is common in women with multiple sex partners and is caused by the overgrowth of several facultative and anaerobic bacterial species. Vulvovaginal candidiasis is characterized by pruritis and a curd like discharge. Vaginal trichomoniasis is associated with a copious yellow or green, sometimes frothy, discharge. ${ }^{3}$

Women often seek medical care for vaginal complaints. Sometimes the cause of the complaint(s) is misdiagnosed by the women. These vaginal complaints may be related to infections, which when misdiagnosed or maltreated can lead to more severe problems. This study was undertaken to find out the different etiological causes of vaginal discharge.

\section{Methods}

Two hundred and fifty sexually active females in the age group of 15-45 years, with complains of vaginal discharge, with or without itching attending at the OPD of Obstetrics and Gynaecology department of Sir Salimullah Medical College and Hospital, Dhaka, were selected for this study at random. A detailed clinical history and a thorough examination of all these cases were done. After making the clinical diagnosis, appropriate tests for diagnosing candidiasis, trichomoniasis, gonorrhea and bacterial vaginosis were performed. A sterilized Cusco's speculum was inserted into the vagina to visualize the vagina and cervix. Any pathology of vagina and cervix like vaginitis, discharge, cervicitis, cervical erosions were looked for. The amount, color, character and smell of the vaginal discharge were noted. The discharge was then collected by three sterile swabs from each woman from the upper part of the posterior fornix and lateral vaginal walls. The swabs of vaginal discharge were processed as follows: (i) One swab was used to inoculate two plates of Sabouraud's dextrose agar medium, one incubated at $22^{\circ} \mathrm{C}$ and another at $37^{\circ} \mathrm{C}$ for 24 and 48 hours for the identification of Candida species; (ii) Second swab was used for wet mount preparation of microscopic examination with $10 \% \mathrm{KOH}$ preparation; and (iii) Third swab was used for making smears for Gram staining.

\section{Laboratory Procedures}

\section{For Candida}

(i) $\mathrm{KOH}$ preparation: A drop of $10 \% \mathrm{KOH}$ was added to the vaginal secretions taken on a clean glass slide and mounted with a cover slip. Candida was identified as highly refractile, round or oval budding yeast cells. (ii) Gram stained vaginal smears were examined which showed Gram positive budding yeast cells with pseudohyphae. (iii) Cultures on Sabouraud's dextrose agar medium showed a growth of creamy, grayish moist colonies. Saline wet mount preparation of the colony showed budding yeast cells and pseudohyphae.

\section{For Trichomonas vaginalis}

Specimens for the wet smear examination were taken from the posterior fornix with a sterilized cotton swab and mixed with a drop of normal saline taken on a clean glass slide. A cover slip was mounted on the glass slide and the wet film was examined immediately under a microscope for flagellate organisms with characteristic motility.

\section{For Neisseria gonorrheae}

A gram stained smear of the discharge from the endocervix was examined under microscope for intracellular Gram negative diplococci.

\section{For bacterial vaginosis}

This was detected by three out of four Amsel's criteria:. (i) Wet film: The discharge from the posterior fornix was taken with a sterilized cotton swab and mixed with a drop of normal saline taken on clean glass slide. A cover slip was mounted on the glass slide. The wet film was examined for the presence of clue cells which are vaginal epithelial cells with a granular surface and blurred margins because of attached bacteria. (ii) Amine test or whiff test: A drop of $10 \% \mathrm{KOH}$ was put on vaginal secretions taken on a glass slide and presence of ammonical odor was noticed. (iii) Gram stained smear: These smears were examined for presence of altered vaginal flora in form of Gram negative cocco-bacilli studding vaginal epithelial cells instead of normally predominant Gram positive Lactobacilli. The vaginal epithelial cells in cases of bacterial vaginosis were having a granular surface and blurred margins because of the attached bacteria (clue cells).

\section{Non-specific urogenital causes}

The cases with complaints of vaginal discharge and other associated symptoms, but with all the other tests negative were grouped under other non-specific urogenital causes of vaginal discharge.

\section{Results}

A total of 250 patients presented with abnormal vaginal discharge were examined; of these, 237 (94.8\%) cases were organism positive. Among the positive cases, vaginal candidiasis $(53.6 \%)$ was the most common microbiologicalcause of abnormal vaginal discharge, 
followed by bacterial vaginosis $(29.2 \%)$, trichomoniasis $(10.8 \%)$, gonorrhea $(1.2 \%)$ and non-specific other urogenital causes $(5.2 \%)$ (Table 1).

The most common age group affected by vaginal candidiasis was the 26-35 years (64.9\%), followed by $36-40$ years $(20.1 \%), 15-25$ years $(12.7 \%)$ and more than 40 years $(2.2 \%)$ (Table 2).

Table 1: Different microbiological etiology of abnormal vaginal discharge among the cases

\begin{tabular}{|l|c|c|}
\hline $\begin{array}{l}\text { Aetiology of abnormal } \\
\text { vaginal discharge }\end{array}$ & $\begin{array}{c}\text { Number of patients } \\
(\mathrm{n}=250)\end{array}$ & Percent \\
\hline Vaginal candidiasis & 134 & $53.6 \%$ \\
\hline Bacterial vaginosis & 73 & $29.2 \%$ \\
\hline Trichomoniasis & 27 & $10.8 \%$ \\
\hline Gonorrhea & 03 & $1.2 \%$ \\
\hline Organism not found & 13 & $5.2 \%$ \\
\hline
\end{tabular}

The bacterial vaginosis was found in high frequency at the age group of 26-35 years (27.6\%), followed by $36-40$ years $(15.7 \%), 15-25$ years $(12.7 \%)$ and more than 40 years $(1.5 \%)$. Trichomoniasis was detected in the highest rate at the age group of $15-25$ years $(52.0 \%)$, followed by $26-35$ years (40.0\%). Gonorrhea was recorded in the age group of 15-25 years $(66.7 \%)$ and $26-35$ years $(33.3 \%)$. All the patients aged $=35$ years $(\mathrm{n}=182)$ were diagnosed with vaginal infections and in this patient group, Candida species, Trichomonas vaginalis and Neisseria gonorrheae are more common than those in patients with age $>35$ years (Table 3 ).

\section{Discussion}

Vaginal discharge is a common presenting symptom observed by general practitioners, gynecologists, and those working in family planning clinics and departments of genitourinary medicine. ${ }^{6}$ As with urethral discharge, vaginal discharge may be either physiological or pathological in origin. It is difficult to know what proportion of discharges belong to either category. Although many cases of abnormal vaginal discharge are not caused by sexually transmitted infections, common curable sexually transmitted infections can present with this symptom. Controlling the spread of sexually transmitted infections and HIV are key public health priorities worldwide. ${ }^{8}$ Recent advances are changing investigation techniques and the management of vaginal discharge.

In this study, organisms responsible for abnormal vaginal discharge are found in $94.8 \%$ of the cases. Vaginal candidiasis $(53.6 \%)$ is the most common microbiological cause of abnormal vaginal discharge. Nessa et al. ${ }^{9}$ reported a similar result in Bangladesh. A similar result was also reported by Nwadioha et al. ${ }^{10}$ and Sobel et al..$^{11}$. Mitchell ${ }^{12}$ found high rate of vaginal candidiasis (75\%) which is higher than the present study. Though the vaginal candidiasis is the highest diagnosed disease, the reason of low incidence in this study may be due to the collection of samples during winter season when vaginal candidiasis is found at a low rate because of cold weather.

Bacterial vaginosis or BV (29.2\%) is the second most common disease found in this study which is similar to the study conducted by Begum et al. ${ }^{13}$ in Bangladesh. Koumans et al. ${ }^{14}$ who had also found a $29.2 \%$ prevalence of BV which is consistent with the present study. Allsworth \& Peipert ${ }^{15}$ reported that almost one third of women $(29 \%)$ were positive for bacterial vaginosis, which is consistent with the present study. Whereas Nessa et al. ${ }^{9}$ in Bangladesh reported 48.1\% cases of bacterial vaginosis among the sex workers which is dissimilar with the present study. This high prevalence may be the result of disturbance of vaginal microflora resulting from frequent sexual intercourse and the subsequent frequent washing with water and disinfectant.

The frequency of Trichomonas vaginalis which is the etiological agents of trichomoniasis was detected in a similar rate $(10.8 \%)$ by Nessa et al. ${ }^{9}$, Rahman et al. ${ }^{16}$ and Alam et al. ${ }^{17}$ in Bangladesh. Adad et al. ${ }^{18}$, Plitt et al. ${ }^{19}$ and Peer et al. ${ }^{20}$ also reported a similar result. Bachmann et al. ${ }^{21}$ reported a prevalence of $22 \%$, whereas Lally et $a l^{22}$ showed a prevalence of $43 \%$ among women at a substance abuse treatment center. The low prevalence of trichomoniasis reported from the present study compared with other studies is surprising and the reason is that the detection of trichomoniasis in this study was by conventional wet mount

Table 2: Distribution of the study population according age and infections

\begin{tabular}{|l|c|c|c|c|c|}
\hline \multirow{2}{*}{ Age group (years) } & \multicolumn{5}{|c|}{ Number of cases $(\mathrm{n}=250)$} \\
\hline & Vaginal candidiasis & Bacterial vaginosis & Trichomoniasis & Gonorrhea & No organism found \\
\hline $15-25$ & $17(12.7 \%)$ & $15(12.7 \%)$ & $15(52 \%)$ & $2(66.7 \%)$ & 0 \\
\hline $26-35$ & $87(64.9 \%)$ & $37(27.6 \%)$ & $10(40 \%)$ & $1(33.3 \%)$ & 0 \\
\hline $36-40$ & $27(20.1 \%)$ & $21(15.7 \%)$ & $2(8 \%)$ & 0 & $3(23.1 \%)$ \\
\hline$>40$ & $3(2.2 \%)$ & $2(1.5 \%)$ & 0 & 0 & $10(76.9 \%)$ \\
\hline Total & 134 & 73 & 27 & 3 & 13 \\
\hline
\end{tabular}


Table 3: Distribution of Organisms according to age groups

\begin{tabular}{|l|c|c|c|}
\hline \multirow{2}{*}{ Vaginal samples } & \multicolumn{2}{c}{ Age group } & \multirow{2}{*}{$p$ value } \\
\cline { 2 - 4 } Candida species & $104(57.1 \%)$ & $30(44.1 \%)$ & 0.066 \\
$\begin{array}{l}\text { Gardnerella } \\
\text { vaginalis }\end{array}$ & $50(27.5 \%)$ & $23(33.9 \%)$ & 0.326 \\
$\begin{array}{l}\text { Trichomonas } \\
\text { vaginalis }\end{array}$ & $25(13.7 \%)$ & $2(2.9 \%)$ & $0.014^{*}$ \\
$\begin{array}{l}\text { Neisseria } \\
\text { gonorrheae }\end{array}$ & $3(1.7 \%)$ & 0 & 0.287 \\
\hline $\begin{array}{l}\text { Organism not found } \\
\text { Total }\end{array}$ & 0 & $13(19.1 \%)$ & $0.001^{*}$ \\
\hline
\end{tabular}

*Values are significant $p<0.05$

microscopy method. However, the high prevalence was due to the using of PCR which increases the high rate of detection of trichomoniasis from vaginal discharge. ${ }^{23}$

Neisseria gonorrheae $(1.2 \%)$ is detected in a very low isolation rate in this study. This result is similar to Nwadioha et $a l^{10}$ and Plitt et al. ${ }^{19}$ Bhuiyan et al. ${ }^{24}$ and Nessa et al. ${ }^{9}$ reported a slightly higher rate of isolation in Bangladesh which is incoherent with the present study. The reason of this may be the study group; the earlier studies were performed in sex workers, whereas the present study covered women attended at the OPD of the hospital.

Due to limitations of the study, the STDs like Chlamydia and non-infective causes of abnormal vaginal discharge are grouped as non-specific other urogenital causes, the detection rate of which is $5.2 \%$. Plitt et al. ${ }^{19}$ and Nwadioha et $a l .{ }^{10}$ reported the reasons of abnormal vaginal discharge due to these causes and were more or less similar to the present study.

The vaginal candidiasis in the present study is profound at the age of 26 to 40 years $(57.1 \%)$. Nwadioha et al. ${ }^{10}$, Rylander et $a l .{ }^{25}$ and Stricker et $a l .{ }^{26}$ reported a similar result. The reason for the high isolation rate in this age group is increased sexual activity, which causes the vaginal candidiasis infection more repeatedly. Candidiasis is not usually a sexually transmitted disease; however, male contacts could be possibly involved. Bacterial vaginosis is found in high frequency at the age group of 26-35 years $(27.6 \%)$ followed by $36-40$ years (15.7\%). A similar result was reported by Madhivanan et al. ${ }^{27}$ and Bukusi et al..$^{28}$ and they added that the bacterial vaginosis is more common in the younger age group. The reason of high rate of isolation may be due to multiple sex partners which causes disruption of normal vaginal flora. Trichomonas vaginalis is detected in the highest rate at the age group of $15-25$ years (52\%), followed by $26-35$ years $(40.0 \%)$. A similar result was reported by Plitt et al. ${ }^{19}$ and they found that the frequency rate was high among sexually active women. Gonorrhea is recorded more in the age group of $15-25$ years $(66.7 \%)$ followed by $26-35$ years $(33.3 \%)$. A similar result was found by Plitt et al..$^{19}$ in Maryland, USA.

\section{Conclusion}

In conclusion, this study permits to conclude that the causative agents of vaginal candidiasis, bacterial vaginosis and trichomoniasis are the most commonly found infectious agents in abnormal vaginal discharge among sexually active women in Dhaka. Clinicians need to be aware of emerging epidemiological data, the different presentations of vaginal discharge, and the approach of their management so that the symptom can be treated according to its etiology. It is recommended that prevention, early diagnosis and prompt treatment of abnormal vaginal discharge especially among the sexually active women should be done in order to avoid the complications and reduce HIV transmission.

\section{References}

1. Fox KK, Behets FM. Vaginal discharge. How to pinpoint the cause. Postgrad Med 1995; 98:87-90.

2. Macsween KF, Ridgway GL. The laboratory investigation of vaginal discharge. J Clin Pathol 1998;51:564-7.

3. Cullins VA, Dominguez L, Guberski T. Treating vaginitis. Nurse Pract 1999;24:46-58.

4. Levett PN. Aetiology of vaginal infections in pregnant and nonpregnant women in Barbados. West Indian Med $J 1995 ; 44: 96-8$.

5. Amsel R, Totten PA, Spiegel CA, Chen KC, Eschenbach D, Holmes KK. Nonspecific vaginitis: diagnostic criteria and microbial and epidemiologic associations. Am JMed 1983;74:14-22.

6. Adler MW. Vaginal discharge: Diagnosis. BMJ 1983; 287:1529-31.

7. Spence D, Melville C. Vaginal discharge. $B M J$ 2007;335:1147-51.

8. Glasier A, Gulmezoglu MA, Schmid GP, Moreno GC, Look VPFA. Sexual and reproductive health: a matter of life and death. Lancet 2006; 368: 1595-1607.

9. Nessa K, Waris SA, Alam A, Huq M, Nahar S, Chawdhury FAH et al. Sexually transmitted infections among brothel-based sex workers in Bangladesh: High prevalence of asymptomatic infection. Sex Transm Dis 2005;32:13-9.

10. Nwadioha SI, Egah DZ, Alao OO, Iheanacho E. Risk factors for vaginal candidiasis among women attending primary health care centers of Jos, Nigeria. J Clin Med Res 2010;2:110-3.

11. Sobel JD, Faro S, Force RW, Fox B. Vulvovaginal candidiasis: epidemiologic, diagnostic, and therapeutic considerations. Am JObstet Gynecol 1998;178:203-11. 
12. Mitchell H. Vaginal discharge-causes, diagnosis, and treatment. BMJ2004: 328:1306-8.

13. Begum N, Muazzam N, Shamsuzzaman SM, Islam MDU, Chowdhury AK, Begum SA. Prevalence of bacterial vaginosis among the PID patients in Bangladesh. Faridpur Med Coll J2011;6:10-3.

14. Koumans EH, Sternberg M, Bruce C, McQuillan G, Kendrick J, Sutton M et al. The prevalence of bacterial vaginosis in the United States, 2001-2004; associations with symptoms, sexual behaviors, and reproductive health. Sex Transm Dis 2007;34:864-9.

15. Allsworth JE, Peipert JF. Prevalence of bacterial vaginosis: 2001-2004 National Health and Nutrition Examination Survey data. Obstet Gynecol 2007; 109:114-20.

16. Rahman M, Alam A, Nessa K, Hossain A, Nahar S, Datta D, et al. Etiology of sexually transmitted infections among street-based female sex workers in Dhaka, Bangladesh. J Clin Microbiol 2000;38:1244-6.

17. Alam N, Rahman M, Gausia K, Yunus M, Islam N, Chaudhury $\mathrm{P}$ et al. Sexually transmitted infections and risk factors among truck stand workers in Dhaka, Bangladesh. Sex Transm Dis 2007;34:99-103.

18. Adad SJ, de Lima RV, Sawan ZTE, Silva ML, de Souza MA, Saldanha JC et al. Frequency of Trichomonas vaginalis, Candida sp and Gardnerella vaginalis in cervical-vaginal smears in four different decades. São Paulo MedJ2001;119:200-5.

19. Plitt SS, Garfein RS, Gaydos CA, Strathdee SA, Sherman SG, Taha TE. Prevalence and correlates of Chlamydia trachomatis, Neisseria gonorrhoeae, Trichomonas vaginalis infections, and bacterial vaginosis among a cohort of young injection drug users in Baltimore, Maryland. Sex Transm Dis 2005; 32:44653.

20. Peer AK, Hoosen AA, Seedat MA, Ende VDJ, Omar MAK. Vaginal yeast infections in diabetic women. South Afr Med J 1993; 83: 727-9.
21. Bachmann LH, Lewis I, Allen R, Schwebke JR, Leviton LC, Siegal HA et al. Risk and prevalence of treatable sexually transmitted diseases at a Birmingham substance abuse treatment facility. Am J Public Health 2000; 90:1615-8.

22. Lally MA, Alvarez SB, Macnevin R, Cenedella C, Dispigno M, Harwell JI et al. Acceptability of sexually transmitted infection screening among women in shortterm drug treatment. Sex Transm Dis 2002; 29:752-5.

23. Madico G, Quinn TC, Rompalo A, McKee KT, Gaydos C. Diagnosis of Trichomonas vaginalis infection by PCR using vaginal swab samples. J Clin Microbiol 1998; 36: 3205-10.

24. Bhuiyan BU, Rahman M, Miah MRA, Nahar S, Islam $\mathrm{N}$, Ahmed $\mathrm{M}$ et al. Antimicrobial susceptibilities and plasmid contents of Neisseria gonorrhoeae isolates from commercial sex workers in Dhaka, Bangladesh: Emergence of high-level resistance to Ciprofloxacin. J Clin Microbiol 1999; 37:1130-6.

25. Rylander E, Berglund A, Krassny C, Petrini B. Vulvovaginal candida in a young sexually active population: prevalence and association with orogenital sex and frequent pain at intercourse. Sex Transm Infect 2004; 80:54-7.

26. Stricker T, Narratil F, Sennhauser FH. Vaginal foreign bodies. J Pediatr Child Health 2004;40:205-7.

27. Madhivanan P, Krupp K, Chandrasekaran V, Karat C, Arun A, Cohen CR, Reingold et al. Prevalence and correlates of bacterial vaginosis among young women of reproductive age in Mysore, India. Indian $\mathrm{J} \mathrm{Med}$ Microbiol 2008;26:132-7.

28. Bukusi EA, Cohen CR, Meier AS, Waiyaki PG, Nguti $\mathrm{R}$, Njeri JN et al. Bacterial vaginosis: risk factors among Kenyan women and their male partners. Sex Transm Dis 2006: 33:361-7. 